ITPD

3,2

82

Received 18 January 2019

Revised 3 May 2019

Accepted 20 May 2019

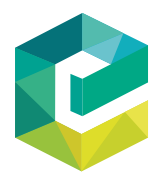

International Trade, Politics and Development

Development
Vol. 3 No. 2, 2019

pp. $82-99$

Emerald Publishing Limited

2586-3932

DOI 10.1108/ITPD-05-2019-0003

\section{The politics of the executive, legislative veto players and foreign debt}

\author{
Seung-Whan Choi \\ University of Illinois at Chicago, Chicago, Illinois, USA, and \\ Shali Luo \\ University of Missouri, Columbia, Missouri, USA
}

\begin{abstract}
Purpose - The purpose of this paper is to examine a curvilinear effect of legislative constraints on foreign debt. Design/methodology/approach - A cross-sectional, time-series data analysis of 68 developing countries during the period from 1981 to 1999 was performed.

Findings - Foreign borrowing is most likely to increase at both low and high levels of legislative constraints, while it is most likely to decrease at moderate levels.

Originality/value - The paper is a first-cut empirical analysis of a curvilinear relationship between legislative constraints and foreign debt.
\end{abstract}

Keywords The executive, Legislative veto players, Foreign debt, Curvilinear effect, Empirical analysis

Paper type Research paper

During the 1980s and early 1990s, many developing countries were plagued by astronomical foreign debt and the possibility of default. The debt crisis could have shattered the entire infrastructure of international financial and political systems (Gilpin, 1987, p. 317). As a result, academics and policy makers alike have had great interest in explaining and understanding why and how the debt crisis occurred. Although economists were the first to pay attention to the causes of the crisis by examining various negative macroeconomic developments, including a worldwide recession, reduced export sales and a sharp increase in interest rates, they tended to overlook political dimensions (e.g. Cline, 1995; Manzocchi, 1997). Several political economists have started to fill the gap by exploring the effect that such political factors as state autonomy, political instability and democratic governance had upon the crisis (e.g. Kaufman and Stallings, 1989). However, prior analyses have neglected the importance of institutional settings in analyzing how foreign debt is determined, especially variations in the policy-making power configuration between the executive and the legislature.

To conceptualize how executive and legislative policy-making powers influence the ebb and flow of foreign borrowing, we borrow from Tsebelis' $(1995,1999,2002)$ seminal work on veto players and then improve his theory by using some key concepts from other institutional approaches (see also Choi, 2010). Since Tsebelis explains that political constraints are characterized by the number of legislative veto players, their preferences and their cohesion, we use the term, legislative constraints, to develop our theoretical argument. When we strictly follow the main tenet of Tsebelis' veto player theory, we expect an inverse linear relationship between legislative constraints and foreign borrowing.

(C) Seung-Whan Choi and Shali Luo. Published in International Trade, Politics and Development. Published by Emerald Publishing Limited. This article is published under the Creative Commons Attribution (CC BY 4.0) licence. Anyone may reproduce, distribute, translate and create derivative works of this article (for both commercial and non-commercial purposes), subject to full attribution to the original publication and authors. The full terms of this licence may be seen at http://creative commons.org/licences/by/4.0/legalcode 
However, after incorporating two additional assumptions about legislative behavior, we propose a U-shaped relationship between the two factors. We theorize that foreign debt is most likely to increase at both low and high levels of legislative constraints, while it is most likely to decrease at middle levels. Based on a cross-sectional, time-series data analysis of 68 developing countries during the period from 1981 to 1999, we uncover that the relationship between the distribution of legislative constraints and foreign debt is indeed curvilinear.

In the next section, we present a brief discussion of literature review. By bridging the veto players theory with other institutional approaches, Section 2 offers a novel conceptual link between legislative constraints and foreign debt. Section 3 includes details of the research design, including both models' specification, operationalization and data sources. Following the research design, Section 4 encompasses the empirical findings and a discussion of the implications. Lastly, we conclude with a brief summary and policy implications.

\section{Brief literature review}

The existing literature can be categorized into three groups. The first group of studies provides macroeconomic explanations. They link economic development, economic growth, exports, budget deficit, government consumption and IMF participation to the rise and fall of foreign debt (e.g. Wiesner, 1985; Kaufman and Stallings, 1989; Cline, 1995; Manzocchi, 1997; Potter, 2000; Vreeland, 2007). For example, quantitative studies such as Cline (1995) and Aggarwal (1996) explore the determinants of sovereign default in times of economic crisis. The second group pays attention to the type of regime (e.g. Olson, 1993; Oatley, 2010; Dasgupta and Ziblatt, 2016). It contends that democratic and autocratic countries have different political discount rates, which influence the borrowing and investment decisions of the government in a different way. For example, Easterly (2002) argues that because autocrats wish to stay longer in power, they are more likely to continue to borrow from the future in order to entertain/bribe their key supporters. By underscoring institutional constraints on the top executive as the democratic advantage, the third group further refines the second group (e. g. Cox and Saiegh, 2018). North and Weingast (1989) are the first to conceptualize that constitutional checks and balances play an important role in resolving commitment problems for the repayment of public debt. As government commitment and credibility increases, interest rates on public bonds should fall and reduce the need for debt financing. But several researchers later dispute the democratic advantage argument. For example, Biglaiser and Staats (2012) demonstrate that credit-rating agency bond raters do not care about the regime type itself but are rather interested in the stability of a certain government system, whether it is democratic or not. Along the same line, Yu's (2016) cross-sectional, time-series analysis for the years 1970-2010 finds that political instability increases the likelihood of default.

By proposing a novel theoretical argument about the curvilinear, rather than linear, relationship between legislative constraints and foreign debt, our study improves the argument of the third group. The rationale is that the previous studies are still debating whether or not political factors such as regime type and institutional constraints are benign forces in addressing the accumulation of foreign debt and the debate is based on the assumption that political constraints/instability are linearly associated with foreign debt. Since the degree of political constraints and linear causality are important unresolved issues in the current literature, we look into them from new theoretical and empirical perspectives - exploring the curvilinear effect of legislative constraints.

\section{The executive, legislative constraints and foreign debt}

Why and how foreign debt changes for individual countries may require multiple causal explanations if the uniqueness of each case were to be scrutinized. To illustrate, Nicolae Ceausescu, the dictator of Romania from 1965 until December 1989, decreased debt by refusing to allow new loans; in contrast, however, Argentina had an explosion of debt 
ITPD

3,2

when the central government was forced to take over the loans of the provinces. Although each of these cases should increase our knowledge about a particular debt problem, it pays little attention to finding a general pattern that reflects the nature of the ebb and flow of foreign debt across a large number of countries over several time periods. In this study we argue that, ceteris paribus, the political constraints which legislative veto players impose on the executive are an important predictor for foreign debt.

From a unified theoretical perspective, Tsebelis' $(1995,1999,2002)$ theory of veto players is the most sophisticated available in the literature of domestic political institutions. Tsebelis defines veto players as a certain number of individual or collective actors whose consensus is necessary for significant policy change, especially legislative change. This can be formulated both positively and negatively. On one hand, since the presence of multiple legislative veto players tends to thwart arbitrary policy changes by the executive, consistent and credible policy commitment is ensured. However, the flip side of this reasoning suggests that the inclusion of more legislative veto players leads to a political stalemate and thus causes policy reforms to be delayed or to even become impossible. In Tsebelis' (2002, p. 204) own words, "'high level of commitment' is another way of saying 'inability for political response."

Existing applications of Tsebelis' $(1995,1999,2002)$ veto players theory to economic performance provide evidence that there is an inverse linear relationship between the distribution of legislative constraints and policy outcomes: the difficulties of enacting significant policy changes grow as the number of legislative veto players increases, as their preferences or ideological distance grows, and as their internal coherence weakens. Accordingly, if the veto players theory is applied to explain a cause of foreign debt which is assumed to be a function of increased spending (for the sake of simplicity), it would predict an inverse linear relationship between legislative constraints and indebtedness. Countries with a low level of legislative constraints are subject to a heavy concentration of veto authority in the hands of the executive and thus are more prone to pushing for expansionary spending bills, resulting in more foreign borrowing. Countries with a high level of legislative constraints are geared toward dispersal of decision-making authority and thus face political stalemates between the executive and congressional legislators with respect to spending, a situation which requires less foreign borrowing. Simply put, the more legislative constraints that are placed on spending, the less foreign debt accrues. Thus, an inverse linear hypothesis concerning the relationship between legislative constraints and foreign debt is drawn as follows:

\section{H1. Foreign debt decreases in proportion as legislative constraints increase.}

However, our hypothesis proposes that the relationship should be curvilinear: foreign debt varies non-linearly dependent on the level of legislative constrains. The possibility of such non-linearity requires correcting an implicit assumption of $H 1$, namely, that the executive is the only actor who seeks to increase government expenditure, while the legislature acts as a political barrier to the executive's spending desire. In contrast, we argue that both executive and congressional legislators have incentives to increase spending for their own political goals, and that variations in the policy-making power between the executive and the legislature non-linearly influence foreign debt.

Specifically, we introduce two assumptions to explain the possibility of such non-linearity. First, it is assumed that because the executive and legislators face incentives to enhance their personal reputations for re-election, they seek to maximize spending power to benefit their particular constituents, which requires more borrowing from abroad. Second, it is assumed that the politics of foreign debt is explained in the context of three different configurations of domestic institutional settings which result from executive-legislative interactions: highly unconstrained political systems in which the executive is dominant in policy-making processes, highly constrained political systems in which congressional legislators are 
dominant, and moderately constrained political systems in which the balance of power between the executive and the legislature prevails, enabling each institution to possess a mutual veto.

\subsection{Highly unconstrained political systems and foreign debt}

Highly unconstrained political systems are created when the executive him/herself possesses necessary and sufficient policy-making power to change the status quo or when the executive's party controls Congress. In cases of single-party parliamentary governments, prime ministers are the most influential policy makers since there is no legislative veto by definition, assuming that there is no high degree of party factionalism. The UK, Japan, at times India and Canada are examples, to name a few. In cases of presidential systems under a unified government, the legislature is considered to possess no effectual veto power.

Anticipating no legislative opposition in highly unconstrained institutional settings, the executive is capable of directly introducing his/her particularistic spending bills to Congress. These spending bills purport to be in line with the executive's economic interests, thus elevating his/her personal reputations for re-election. In Kieweit and McCubbins' (1985, p. 182) words, "the president's preferences [...] derive in large part from the imperative of preserving an electoral coalition. This requires providing benefits to constituent groups" (see also Cox and McCubbins, 2001). Cheng and Haggard's (2001, p. 224) study on Taiwan's budget policy provides empirical evidence that "the president and the ruling party have had to cultivate ties with new constituencies (business, the middle class, and environmentalists), largely via private-regarding policy - that is, by providing more targeted and particularistic pork-barrel expenditures." If the executive initiates costly projects that aim at buying the legitimacy from his/her target constituency such as big campaign donors (e.g. big construction business corporations), it leads to a high capacity of changing the status quo toward an expansionary spending direction because it permits the executive to squander financial resources for personal political ambitions, leading to an increase of foreign borrowing.

This understanding of "unconstrained" political systems is very much in line with the veto players theory. Inadequate legislative checks and balances imply that the executive is capable of making unitary spending policy decisions, resulting in waste or mismanagement of the funds received. If the executive intends to favor a subset of the entire population for his/her re-election, he/she could simply ignore potential threats from ineffectual legislative veto players. In this sense, elected legislators become rubber stamps, rather than part of the real policy-making process regarding budget spending. It is not surprising to find desperate debt conditions, especially under authoritarian regimes such as in Indonesia, Malaysia and Zaire, in which the norm is a one-man rule coupled with ineffectual veto players like titular political parties (Haggard, 1986; MacIntyre, 2003).

\subsection{Highly constrained political systems and foreign debt}

Highly constrained political systems are found in countries where policy-making power skews toward the hands of congressional legislators, especially in coalition governments. The ascendance of legislative power offers legislators opportunistic chances to maximize their re-election goals through expansionary spending bills. As Crepaz (2002, p. 174) puts it, "there is an inherent bias of coalition governments for expansionary policies through logrolling mechanisms. The logic of this expansive behavior among coalition partners is rather straightforward: individual coalition partners have distinctive constituencies and distinctive interests" (see also Crepaz and Moser, 2004). Such parochial interests combined with re-election goals motivate legislators to push for more spending for particular constituents; the resulting prediction is that more parties or actors involved in a legislative coalition will lead to greater government spending. This stands in marked contrast to the 
ITPD

3,2

veto players theory which predicts that larger coalitions-which are increases in veto players as each party in a coalition exercises a veto in its ability to bring down the government-result in policy stability, leading government spending to remain at the initial status quo. The reason for this difference is a more nuanced understanding of legislative behavior or, rather, the institutional determinants of legislative behavior in regards to spending.

Elected legislators often have enormous incentives to make themselves personally known to prospective voters by providing particularistic or pork-barrel rewards such as infrastructure projects or legislation which allows local business companies greater access to foreign funds (Crisp et al., 2004). As such, each legislator has an incentive to increase spending for his/her own constituencies, even if their overall goal is to decrease government spending. These incentives create a collective action problem: each party attempts to decrease government spending without trying to give up its own spending desires, resulting in an expansion of government spending precisely because of each party's reluctance to give up their own spending goals. Thus, an increase of foreign debt is the result of distributive logrolls by legislators who face personal vote seeking incentives and behave accordingly (Cox and McCubbins, 2001). This can be restated in regards to the observed political system being "highly constrained": because the executive's veto power is not strong enough to check and balance legislators' proclivity to parochial spending legislation in highly constrained institutional settings, the likely outcome is an upsurge of foreign debt, private or public.

\subsection{Moderately constrained political systems and foreign debt}

Moderately constrained political systems refer to institutional settings in which the balance of policy-making power between the executive and the legislature is maintained. In such circumstances, both the executive and the legislature effectively exercise mutual veto powers to put checks and balances on the other side's policy preferences. Because both institutions have the ability to apply brakes to a policy decision-making process, they are essentially capable of vetoing a spending policy change targeted at particularistic interests, diminishing the necessity of foreign borrowing. When the executive pursues expansionary spending policies for particular constituents, congressional legislators are capable of hindering the executive's impulse to particularism. Conversely, when congressional legislators demand to increase spending expenditures for their particularistic constituents, the executive is able to simply exercise his/her veto power.

To recap, when either the executive or the legislature is dominant in spending policy-making processes, each side will succumb to electoral incentives by offering particularistic benefits to their constituents, requiring an increase of foreign debt. However, when there is the executivelegislative balance of power, parochial spending bills will be blocked by mutual veto, keeping foreign debt low. Thus, a U-shaped hypothesis concerning the relationship between legislative constraints and foreign debt is drawn as follows:

H2. Foreign debt is likely to worsen in both highly unconstrained and highly constrained institutional settings, while foreign debt is likely to improve in moderately constrained institutional settings.

\section{Statistical model building and operationalization}

To explore the hypothesized linear and curvilinear effects of legislative constraints on foreign debt empirically, two statistical models are considered:

$$
\text { Foreign } \text { Debt }_{i t}=\alpha+\beta_{1}\left(\text { Legislative Constraints }_{i t}\right)+\beta_{2 \text { to } k}\left(\text { Economic Variables }_{i t}\right)+\varepsilon,
$$


Foreign Debt $_{i t}=\alpha+\beta_{1}\left(\right.$ Legislative Constraints $\left._{i t}\right)+\beta_{2}\left(\right.$ Legislative Constraints squared $\left._{i t}\right)$

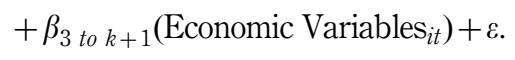

Inferred from Tsebelis' veto players theory, the first equation is built to examine the influence of legislative constraints on indebtedness, while controlling for several economic factors. This equation tests the possibility of the inverse linear relationship expressed in $H 1$. The second equation includes all variables in the first equation plus a squared term for legislative constraints to capture the possible quadratic relationship between legislative constraints and indebtedness expressed in $H 2$ (on quadratic regression; see Agresti and Finlay, 1997, pp. 543-550; Gujarati, 2003, pp. 226-229). The first equation should produce biased estimates on the linear regression prediction line if the relationship between legislative constraints and foreign debt is actually non-linear.

The unit of analysis in these models is a country-year. A cross-sectional, time-series data set for 68 developing countries from 1981 to 1999 was collected from the World Bank's World Development Indicators 2001, which includes no debt data on developed countries and whose data entry ends in 1999 (for the country list, see Table AI). The data analysis consists of two sets of tests. The first test employs cross-sectional, time-series regression models with fixed effects, which allows the intercept to differ among countries in recognition of the fact each country may have some specific characteristics of its own. In their "Dirty Pool" article, Green et al. (2001, p. 442) argue that "analyses of pooled cross-section data that make no allowance for fixed unobserved differences between [countries] often produce biased results." The second test includes maximum-likelihood random-effects regression models, which assume that the intercept of each cross-sectional unit is a random drawing from a much larger population with a constant mean value[1]. These two types of statistical modeling will provide robust empirical testing.

The dependent variable, foreign debt, is operationalized in terms of the change in the ratio of total foreign debt to GDP, which is the first difference of the level of debt. Because the level of indebtedness is unlikely to satisfy the stationarity conditions, the change in indebtedness, which is stationary and random, is instead employed (for the stationarity conditions, see Baltagi, 2001; Gujarati, 2003)[2]. Foreign debt is defined as "debt owed to nonresidents repayable in foreign currency, goods or services. It is the sum of public, publicly guaranteed, and private nonguaranteed long-term debt, use of IMF credit and short-term debt" (World Bank, 2001, p. 257).

For the legislative constraints variable, we use Henisz's (2000a, b) collection which measures the degree of political constraints produced by three institutional veto players: executive, lower and upper legislative chambers[3]. Simply put, the Henize measure assesses the level of political constraints imposed by legislative veto players on the executive. It is a continuous measure on a scale of 0 (lowest) to 1 (highest). It is worth noting that Tsebelis (2002, p. 204) acknowledges that "Henisz's [measure] is conceptually very closely correlated with [my theory of] veto players, and covers an overwhelming number of countries." With Tsebelis' recommendation, it appears that the Henisz measure is the best available measure in assessing the effect of legislative constraints on foreign debt. The legislative constraints squared variable is a squared term for the legislative constraints variable used for the quadratic function. As indicated in the U-shaped hypothesis, the coefficient for legislative constraints should have a negative sign, while that for legislative constraints squared should have a positive sign.

Several economic factors are included as control variables to isolate the independent effect of legislative constraints on foreign debt. With this objective in mind, the following six control variables are considered: economic development, economic growth, exports, budget 
ITPD

3,2

88

deficit, government consumption and IMF participation. What follows is a brief discussion regarding each of these variables.

One of the main concerns of political leaders in developing countries is the development of economic wealth for the well-being of the population. Because there is a shortage of sufficient development funds that can be used to build social and economic infrastructure, developing countries are likely to turn to foreign funds (Gilpin, 1987; Potter, 2000). However, as economic development progresses, developing countries should need less foreign financing for domestic projects. Economic development is measured as the log of GDP per capita.

Economic growth should have a beneficial influence on domestic economies because it generates more usable government revenues to repay foreign debt. Thus, developing countries with expanding economies are likely to reduce indebtedness (Kaufman and Stallings, 1989). Economic growth is operationalized as the annual percentage growth rate of GDP at market prices based on a constant local currency.

Reduced export sales should keep developing countries from achieving the large surpluses on the merchandise and services portion of the current account from which they need to pay interest on their foreign debts. By contrast, an export volume increase or surplus is expected to contribute to the decline of indebtedness (Roett, 1984; Manzocchi, 1997). Exports are measured as the sum of exports of goods and services divided by GDP.

Most literature on international financial transactions highlights the detrimental effect of government deficits on macroeconomic performance. Budget deficits are often financed by foreign borrowing, so developing countries which operate in the red are likely to suffer from severe debt problems. However, the improvement of the budget deficit is anticipated to reduce foreign debt (Wiesner, 1985). Budget deficit is the proportion of deficits in GDP.

The increase of government consumption should produce a demand for foreign capital (Cline, 1995). Government consumption is operationalized as the average general government consumption expressed as a percentage of GDP.

Since IMF's structural adjustment programs are designed to help reduce the borrowing country's fiscal imbalances, their participant countries should be able to pay off the debt which they have accumulated (Vreeland, 2007). IMF participation is recorded as "1" and otherwise as "0."

The first five control variables are collected from the World Bank's World Development Indicators 2001, and the IMF participation variable is obtained from Vreeland's (2007) collection. Table AII provides a summary of the hypotheses and operationalization of the variables; Table AIII shows their descriptive statistics.

Other potential controls such as world interest rates and interest rate differentials between high risk countries relative to the London Inter-Bank Offered Rate (LIBOR) may affect foreign loans, but are not included because of the lack of data for all the countries and years of this study. There are no LIBOR data available before 1986, and this empirical analysis starts from 1981. In addition, the data are calculated daily, not yearly (see www.bba.org.uk/bba/jsp/ polopoly.jsp?d=141). More importantly, it would be very challenging to collect all the interest rates that were applied to the significant variety of loans lent to each country over the two decades of study (e.g. long-term vs short-term interest rates). Each foreign loan agreement is different and involves complicated financial arrangements.

Table I summarizes a matrix of Pearson product-moment correlations between variables. This simple correlation analysis provides some preliminary results: there is an inverse linear relationship between legislative constraints and foreign debt. As legislative constraints increase, indebtedness decreases, which is consistent with the prediction of the veto players theory. The other independent variables, except for government consumption, are negatively related to foreign debt. Before moving on to the multivariate regression results in the next section, a brief discussion of the multicollinearity problems that may be suspected among the 


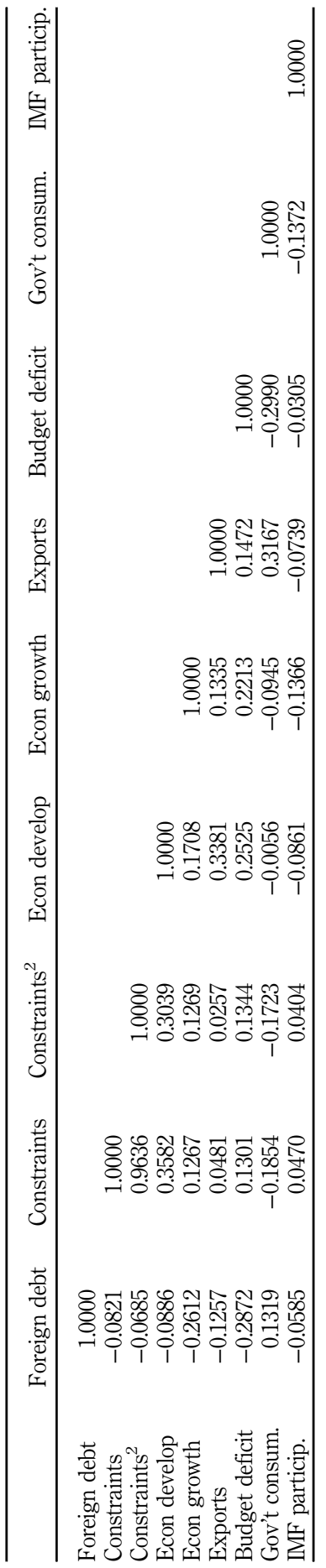

Foreign debt

89

Table I.

A matrix of Pearson product-moment correlations 
ITPD

3,2

90 independent variables is in order. we have conducted three sets of state-of-the-art diagnostic tests for multicollinearity: variance inflation factors (VIFs), $R^{2}$ statistics and condition index (see Belsley et al., 1980; Baltagi, 2001; Gujarati, 2003). As a general rule, a serious multicollinearity problem is suspected if the mean of all the VIFs is considerably larger than 10 , if $R^{2}$ is greater than 0.80 , or if the condition number (that is derived from the eigenvalue) exceeds 1,000. As shown in Table II, none of the diagnostic results indicates severe multicollinearity between any two independent variables.

\section{Results from testing}

Table III shows the multivariate regression results. The results for the inverse linear equation are displayed under odd model numbers 1 and 3 , while those for the curvilinear equation are under even model numbers 2 and 4. Models 1 and 2 depict the results using the fixed-effects regression, but Models 3 and 4 show the results using the maximum-likelihood random-effects regression. A one-tailed test for each variable is employed because all the hypotheses are directional. Following the common practice in studies of international political economy, 0.01, 0.05 and 0.10 are used as significance levels (e.g. Jensen, 2003; see also Li, 2005). Because the estimated autocorrelation coefficient, $\rho$, across the models is close to zero, no serious serial correlation of the first order is suspected.

In Models 1 and 3 where an inverse linear relationship is hypothesized, the coefficient for legislative constraints shows a negative sign with no statistical significance. An increase of legislative constraints does not necessarily lead to a decrease of foreign debt in developing countries. Because the legislative constraints variable turns out to have no meaningful explanatory power, $H 1$ is not supported. In other words, this empirical evidence does not corroborate the prediction of the veto players theory. To test the U-shaped relationship as predicted in H2, Models 2 and 4 include all the same variables as Models 1 and 3 and additionally include a squared term for legislative constraints. As expected, the legislative constraints variable in fixed-effects Model 2 indicates a negative sign and is statistically

\begin{tabular}{lccc}
\hline & Variance inflation factors & Tolerance & $R^{2}$ \\
Legislative constraints & 1.20 & 0.8310 & 0.1690 \\
Economic development & 1.36 & 0.7341 & 0.2659 \\
Economic growth & 1.10 & 0.9067 & 0.0933 \\
Exports & 1.34 & 0.7480 & 0.2520 \\
Budget deficit & 1.25 & 0.7974 & 0.2026 \\
Government consumption & 1.36 & 0.7351 & 0.2649 \\
IMF participation & 1.05 & 0.9491 & 0.0509 \\
Mean variance inflation factors & 1.24 & & \\
& Eigenvalues & 1.0000 & 2.1622 \\
1 & 5.1547 & 2.8258 & 3.3979 \\
2 & 1.1026 & 3.4226 & 6.4197 \\
3 & 0.6455 & 8.1707 & \\
4 & 0.4465 & 24.9029 & 24.9029 \\
5 & 0.4401 & 0.1251 & 0.470
\end{tabular}

inflation factors is considerably larger than 10 , if $R^{2}$ is greater than 0.80 or if condition number (derived from
Table II.

Muliticollinearity diagnostics 


\begin{tabular}{|c|c|c|c|c|c|}
\hline & \multicolumn{2}{|c|}{ Fixed effects } & \multicolumn{2}{|c|}{ Random effects } & \multirow[t]{2}{*}{ reign debt } \\
\hline & Model 1 & Model 2 & Model 3 & Model 4 & \\
\hline Constant & $-0.1096 *(0.0823)$ & $-0.0906(0.0827)$ & $-0.0070(0.0130)$ & $-0.0089(0.0130)$ & \\
\hline Legislative constraints & $-0.0048(0.0130)$ & $-0.0914 * *(0.0458)$ & $-0.0048(0.0084)$ & $-0.0476 *(0.0300)$ & \\
\hline Legislative constraints ${ }^{2}$ & & $0.1709 * *(0.0868)$ & & $0.0852 *(0.0573)$ & \\
\hline Economic development & $0.0165 *(0.0120)$ & $0.0142(0.0120)$ & $0.0019(0.0019)$ & $0.0023(0.0019)$ & \\
\hline Economic growth & $-0.0024 * * *(0.0004)$ & $-0.0024 * * *(0.0004)$ & $-0.0023 * * *(0.0004)$ & $-0.0023 * * *(0.0004)$ & \\
\hline Exports & $-0.0009 * * *(0.0003)$ & $-0.0009 * * * *(0.0003)$ & $-0.0004 * * *(0.0001)$ & $-0.0004 * * *(0.0001)$ & \\
\hline $\begin{array}{l}\text { Budget deficit } \\
\text { Government }\end{array}$ & $-0.0020 * * *(0.0005)$ & $-0.0019 * * * *(0.0005)$ & $-0.0019 * * *(0.0003)$ & $-0.0019 * * *(0.0003)$ & \\
\hline consump & 0.0015 *** $(0.0007)$ & $0.0015 * *(0.0007)$ & $0.0006 * *(0.0003)$ & $0.0006 * *(0.0003)$ & \\
\hline IMF participation & $-0.0054(0.0043)$ & $-0.0051(0.0043)$ & $-0.0094 * * *(0.0034)$ & $-0.0093 * * *(0.0034)$ & \\
\hline$\rho$ & 0.1619 & 0.1467 & 0.0000 & 0.0000 & Table I \\
\hline$R^{2}$ within & 0.1290 & 0.1331 & na & na & The effect of \\
\hline$n$ & 892 & 892 & 892 & 892 & legislative constraints \\
\hline \multicolumn{5}{|c|}{ Notes: Standard errors in parentheses. $* p<0.10 ; * * p<0.05 ; * * * p<0.01$} & \\
\hline
\end{tabular}

significant at the 0.05 level, and the legislative constraints squared variable shows a positive sign and is significant at the 0.05 level. This evidences that foreign debt increases at both low and high levels of legislative constraints, while it decreases at moderate levels. The curvilinear hypothesis is confirmed by random-effects Model 4. Both fixed- and random-effects models reveal the U-shaped relationship between legislative constraints and indebtedness[4]: moderately constrained political systems are associated with the low rate of change in indebtedness, while both highly unconstrained and highly constrained political systems are related to the high rate of change[5].

Among the six independent variables, economic growth, exports, budget deficit and government consumption show significance, regardless of model specifications and estimation methods. The economic growth variable displays a negative sign and is statistically significant, indicating that as long as economic growth continues, foreign debt is more likely to decrease. The significance of the economic growth variable reveals that debt reduction becomes more plausible under a growing economy. The exports hypothesis is also supported in a consistent manner: increasing export revenue is likely to assist a reduction of foreign debt. As expected, when budget deficits (large negative numbers in the data) improve, indebtedness decreases. The government consumption shows a positive sign and is statistically supported. As countries increase spending on goods and services (e.g. defense, judicial system, education, etc.), they need more borrowing from abroad.

To further verify the robustness of the main findings of the curvilinear relationship, two more empirical analyses are conducted. The first analysis is a re-run of Model 2 with year fixed effects instead of country fixed effects. Just as debt problems may be country-specific because some developing countries, such as those in Latin America, are more vulnerable to indebtedness than others, they also may be year-specific since some years are exposed to more severe debt problems than others. The re-run shows that the legislative constraints variable produces a coefficient of -0.0914 with a standard error of 0.0458 , which is statistically significant at the 0.05 level, while the legislative constraints squared variable has a coefficient of 0.1709 with a standard error of 0.0868 , which is also statistically significant at the 0.05 level. These results of the year fixed effects confirm those of the country fixed effects reported in Table III: while foreign borrowing is required less at moderate levels of legislative constraints, it is demanded more at both low and high levels.

It should be noted that in quantitative analyses with a large number of observations, statistical significance does not necessarily indicate a substantively meaningful or important 
ITPD

3,2

92

finding in a practical sense (see Agresti and Finlay, 1997; Baltagi, 2001; Gujarati, 2003). With this concern in mind, we examine the substantive effects of legislative constraints and legislative constraints squared as the second analysis for robustness. For example, in the case of Model 2 in Table III, a change of 1 standard deviation of the legislative constraints variable decreases the rate of change in indebtedness by 726 percent (i.e. from 0.0027 to -0.0169 ), and 2 standard deviations by 1,448 percent (i.e. from 0.0027 to -0.0364). A change of 1 standard deviation of the legislative constraints squared variable increases the rate of change by 693 percent (i.e. from 0.0027 to 0.0214 ), and 2 standard deviations by 1,385 percent (i.e. from 0.0027 to 0.0401 ). The bottom line is that foreign debt varies non-linearly dependent on variations of domestic institutional settings.

These results shed new light on the veto players theory. As noted earlier, existing studies of veto players would argue that mounting legislative constraints should create a political stalemate between the executive and legislators regarding spending increases, thereby requiring no extensive foreign borrowing. In this context, as legislative constraints increase, a decrease of the rate of change in indebtedness is anticipated, which is not consistent with the overall results reported above in Table III. Instead, we find that countries with moderate legislative constraints maintain the low rate of change in indebtedness, while countries with either low or high legislative constraints experience the high rate of change.

Given the fact that the democratic peace theory has been at the center of scholarly debate for the past two decades and that legislative veto players are major policy makers in democratic countries, it seems natural to look into the effect of legislative constraints on foreign debt with respect to the type of regime. However, because the Henisz measure of legislative constraints is not constructed according to the regime type of each country, we identify legislative constraints in democracies and in autocracies using Polity, one of the most-widely used political regime data sets, measuring multidimensional characteristics of democracy (for Polity, see Gurr et al., 1991). A redefined measure of legislative constraints is created by combining the Henisz measure with a dichotomized Polity indicator. A country is defined as a democracy if a composite indicator of Polity on a scale ranging from 0 (least democratic) to 20 (most democratic) is greater than or equal to 10. The cut-off value of 10 follows the practice of previous studies (e.g. Gerring et al., 2005)[6]. The variable of legislative constraints under democratic regimes is coded as equal to the Henisz measure of legislative constraints if a country is identified as a Polity-based democracy and coded zero for a Polity-based autocracy. The main purpose of introducing this method is to further clarify the effects of legislative constraints in democracies vs autocracies, as illustrated in Li's (2005) recent study.

To avoid some confusion about the identification method, it should be stressed that, consistent with the theoretical arguments of the democratic peace theory, political constraints which legislative veto players impose on the executive are conceptualized as the defining feature of liberal democracy because they tend to be more prevalent in democracies than in autocracies. While democratic peace studies use Polity to measure the general implications of democratic governance, this study turns to the Henisz measure to capture the specific implications of legislative constraints. To be precise, my use of the legislative constraints measure examines the exclusive influence of congressional legislators on the executive regarding the feasibility of debt policy changes, whereas Polity detects the overall quality of democratic governance across five sub-dimensions: competitiveness of participation, regulation of participation, competitiveness of executive recruitment, openness of executive recruitment and constraints on the executive (Gurr et al., 1991)[7]. Accordingly, it would be a mistake to claim that the level of legislative constraints increases if and only if the level of Polity increases. In other words, the democracy identification method introduced above is to more precisely differentiate legislative constraints in democracies from those in autocracies by using Polity, but not to claim that there is an interaction effect between legislative constraints and Polity[8]. 
In Table IV, Models 5-8 report results that are similar to those in Table III with the last model as the only exception. There exists no inverse linear relationship between legislative constraints and indebtedness according to Models 5 and 7 , but rather a U-shaped relationship according to Model 6. The random-effects Model 8 appears to be an exception to the curvilinear findings since it shows no statistical significance despite the fact that each of the coefficient signs for the legislative constraints variables is in the right direction (i.e. negative for legislative constraints and positive for legislative constraints squared). By and large, these results again confirm that at moderate levels of legislative constraints, the executive and the legislature possess mutual veto power against particularistic spending increases, keeping foreign debt low. But at both high and low levels of legislative constraints, foreign debt is high.

A possible issue about the curvilinear findings in Tables III and IV may come from an observation that opposition parties under the parliamentary system are unlikely to put significant political constraints on the legislative process (see Tsebelis, 2002; Birchfield and Crepaz, 1998). Put differently, presidents may face higher legislative constraints in policy decision-making than prime ministers. Because the Henisz measure does not differentiate parliamentary systems from presidential systems in a specific way, it may have overestimated the overall influence of parliamentary countries. The results in Table $\mathrm{V}$ take this issue into account by treating parliamentary constraints as "nonexistent (i.e. equal to 0)[9]." The coefficients for legislative constraints and legislative constraints squared are similar to those in Tables III and IV with respect to the coefficient sign and significance level. While no inverse linear relationship between legislative constraints and indebtedness emerges in Models 1, 3, 5 and 7, the U-shaped relationship is found with Models 2, 4 and 6.

\section{Conclusion}

How domestic institutional settings affect foreign debt is an important issue to academics and policy makers alike. However, there has been no existing longitudinal empirical study that explores the determinants of foreign debt from the perspective of the policy-making power dynamics between the executive and the legislature, a relatively understudied area for political scientists. We have conceived of foreign debt as a product of an interaction between re-election-minded executives and congressional legislators, assuming that both pursue distributive or particularistic politics to stay in office longer. Specifically, we have underlined that legislative constraints stemming from the number of legislative veto

\begin{tabular}{lcccr}
\hline & \multicolumn{2}{c}{ Fixed effects } & \multicolumn{2}{c}{ Random effects } \\
& Model 5 & Model 6 & Model 7 & Model 8 \\
\hline Constant & $-0.1118^{*}(0.0826)$ & $-0.0938(0.0831)$ & $-0.0065(0.0130)$ & $-0.0076(0.0130)$ \\
Legislative constraints & $-0.0063(0.0135)$ & $-0.0888^{* *}(0.0473)$ & $-0.0030(0.0083)$ & $-0.0367(0.0312)$ \\
Legislative constraints & & $0.1616^{* *}(0.0887)$ & & $0.0675(0.0602)$ \\
Economic development & $0.0168^{*}(0.0120)$ & $0.0145(0.0120)$ & $0.0017(0.0019)$ & $0.0020(0.0019)$ \\
Economic growth & $-0.0024^{* * *}(0.0004)$ & $-0.0023^{* * *}(0.0004)$ & $-0.0025^{* * *}(0.0004)$ & $-0.0023^{* * *}(0.0004)$ \\
Exports & $-0.0009^{* * *}(0.0003)$ & $-0.0009^{* * *}(0.0003)$ & $-0.0004^{* * *}(0.0001)$ & $-0.0004^{* * *}(0.0001)$ \\
Budget deficit & $-0.0020^{* * *}(0.0005)$ & $-0.0019 * * *(0.0005)$ & $-0.0019 * * *(0.0003)$ & $-0.0019 * * *(0.0003)$ \\
Government & & & & \\
consumption & $0.0015 * *(0.0007)$ & $0.0016^{* *}(0.0007)$ & $0.0006 * *(0.0003)$ & $0.0006 * *(0.0003)$ \\
IMF participation & $-0.0054(0.0043)$ & $-0.0050(0.0043)$ & $-0.0094 * * *(0.0034)$ & $-0.0095 * * *(0.0034)$ \\
$\rho$ & 0.1637 & 0.1477 & 0.0000 & 0.0000 \\
$R^{2}$ within & 0.1291 & 0.1326 & na & na \\
$n$ & 892 & 892 & 892 & 892
\end{tabular}

Notes: Standard errors in parentheses. * ${ }^{*}<0.10 ; * * p<0.05 ; * * * p<0.01$

Table IV.

The effect of legislative constraints (redefined by polity) on foreign debt 
ITPD

3,2

94

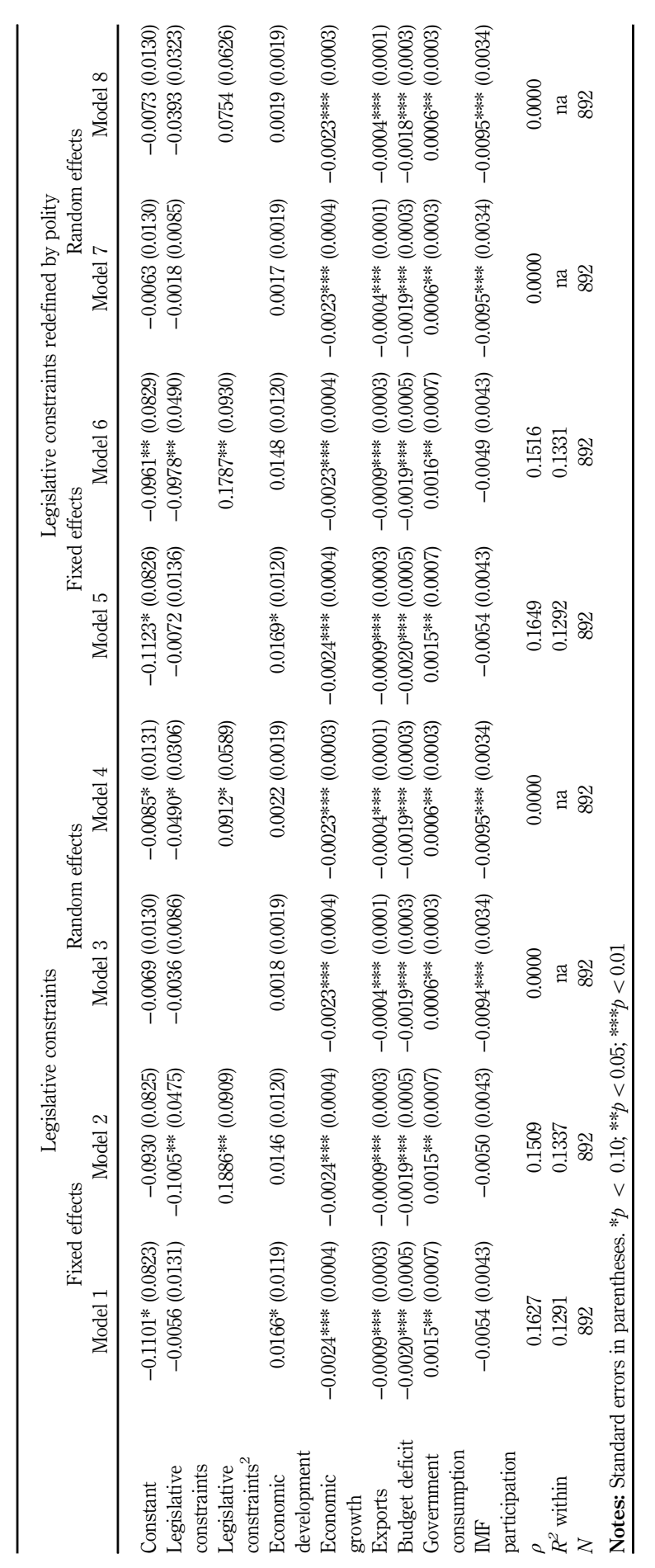

Table V.

The effect of

legislative constraints on foreign debt:

presidential systems 
players, their policy preferences, and their internal coherence should produce a curvilinear influence on the fluctuation of foreign borrowing in developing countries. We have found that in highly constrained developing countries in which legislative constraints outweigh the executive's veto power, the rate of change in foreign debt increases because multiple legislative veto players are likely to increase spending for their particular constituents. In highly unconstrained developing countries in which the executive is free from legislative opposition, the rate of change in foreign borrowing increases because the executive is likely to initiate spending legislation targeted at his/her political supporter. However, in developing countries where the policy-making power is equally distributed between the executive and the legislature, the rate of change in indebtedness is likely to be low because the power parity hinders each institution from fueling the impulse to particularism.

Our findings implicate that to circumvent a potential debt crisis in the future, developing countries should foster political institutions in which policy-making powers are balanced and checked rather than dominated by one player. An ideal power structure should be the existence of constructive legislative oversight over the executive so that the two branches can work together in dealing with any possibility of financial calamity. In addition, our study suggests that when outside economic entities such as IMF, IBRD and ADB provide risk capital for economic development projects or run debt relief programs, they should also consider helping indebted countries with their institutional settings. If a country has a history of chronical debt problems due to an unbridled political power of its top leadership, global development finance institutions should require it to introduce an institutional reform in exchange for their funds. If such a country can cultivate positive policy interactions between the executive and the legislature, it could learn and improve the ability of paying back its government debt in the future.

\section{Notes}

1. Hausman's (1978) specification test, however, shows $\chi^{2}=15.03$ with $p$-value $=0.0585$. This means that under the current specification, our null hypothesis that the country-level effects are adequately modeled by a random-effects model is rejected though not highly significant. For a detailed technical discussion on fixed effects and random effects, see Baltagi (2001) and Gujarati (2003).

2. When the level of indebtedness is used as the dependent variable, the results are similar to those reported below and can be obtained from the author upon request.

3. The data set is publicly available at www-management.wharton.upenn.edu/henisz/

4. As an additional check for robustness, we also report feasible generalized least squares (FGLS) in Table AIV. The main results are consistent with those in Table III. Models 1 and 2 follow the model specification of Table III, while Models 3 and 4 replicate the first two models after adding a control for time changes. The time control is not statistically significant probably because our dependent variable is the change in the ratio of total foreign debt to GDP and because the year fixed effects already account for the uniqueness of each year.

5. The quadratic equations produce a U-shaped curve which has a critical inflection point. Based on the formula for the inflection point (i.e. $-\beta_{1}$ divided by $2 \beta_{2}$; see Agresti and Finlay, 1997, p. 547), 0.2674 is obtained for Model 2 and 0.2793 for Model 4. The closer to the inflection point (i.e. either 0.2674 or 0.2793 ) a country is, the lower its foreign debt is.

6. Some existing studies treat countries whose scores are greater than or equal to 16 as democracies (e.g. Dixon, 1994). The results with the 16 threshold are similar to those reported in this study and can be obtained from the author upon request. We prefer the 10 threshold because it can avoid a criticism that the 16 threshold is too strict to allow more variations among democratic developing countries. 
ITPD

3,2

96

7. It is interesting to note that the validity of Polity remains open to question. For example, Munck and Verkuilen (2002, p. 26) observe that: "not only is virtually no theoretical justification for this operation provided, but it is also open to criticism due to the [Polity] index's problems of conceptual logic."

8. It is also not advisable to test legislative constraints and Polity in the same model because they are conceptually and empirically related to each other.

9. A similar measure is applied to the democratic participation variable in Li's (2005) study.

\section{References}

Aggarwal, V. (1996), Debt Games., Cambridge University Press, New York, NY.

Agresti, A. and Finlay, B. (1997), Statistical Methods for the Social Sciences, Prentice Hall, Upper Saddle River, NJ.

Baltagi, B.H. (2001), Econometric Analysis of Panel Data, 2nd ed., John Wiley \& Sons, New York, NY.

Belsley, D.A., Kuh, E. and Welsch, R.E. (1980), Regression Diagnostics: Identifying Influential Data and Sources of Collinearity, John Wiley \& Sons, New York, NY.

Biglaiser, G. and Staats, J. (2012), "Finding the 'democratic advantage' in Sovereign bond ratings", International Organization, Vol. 66 No. 3, pp. 515-535.

Birchfield, V. and Crepaz, M.M.L. (1998), "The impact of constitutional structures and collective and competitive veto points on income inequality in industrialized democracies", European Journal of Political Research, Vol. 34 No. 2, pp. 175-200.

Cheng, T.-J. and Haggard, S. (2001), "Democracy and deficits in Taiwan: the politics of fiscal policy 1986-1996", in Haggard, S. and McCubbins, M.D. (Eds), Presidents, Parliaments, and Policy, Cambridge University Press, New York, NY, pp. 183-225.

Choi, S.-W. (2010), "Legislative constraints", Journal of Conflict Resolution, Vol. 54 No. 3, pp. 438-470.

Cline, W.R. (1995), International Debt Reexamined, Institute for International Economics, Washington, DC.

Cox, G.W. and McCubbins, M.D. (2001), "The institutional determinants of economic policy outcomes", in Haggard, S. and McCubbins, M.D. (Eds), Presidents, Parliaments, and Policy, Cambridge University Press, New York, NY, pp. 21-63.

Cox, G.W. and Saiegh, S.M. (2018), "Executive constraint and sovereign debt", Comparative Political Studies, Vol. 51 No. 11, pp. 1504-1525.

Crepaz, M.M.L. (2002), "Global, constitutional, and partisan determinants of redistribution in fifteen OECD countries”, Comparative Politics, Vol. 34 No. 2, pp. 169-188.

Crepaz, M.M.L. and Moser, A.W. (2004), "The impact of collective and competitive veto points on public expenditures in the global age", Comparative Political Studies, Vol. 37 No. 3, pp. 259-285.

Crisp, B.F., Escobar-Lemmon, M.C., Jones, B.S., Jones, M.P. and Taylor-Robinson, M.M. (2004), "Voteseeking incentives and legislative representation in six presidential democracies", Journal of Politics, Vol. 66 No. 3, pp. 823-846.

Dasgupta, A. and Ziblatt, D. (2016), "Capital meets democracy", unpublished paper, available at: https://ssrn.com/abstract=2768848; http://dx.doi.org/10.2139/ssrn.2768848

Dixon, W.J. (1994), "Democracy and the peaceful settlement of international conflict", American Political Science Review, Vol. 88 No. 1, pp. 14-32.

Easterly, W. (2002), "How did heavily indebted poor countries become heavily indebted?", World Development, Vol. 30 No. 10, pp. 1677-1696.

Gerring, J., Thacker, S.C. and Moreno, C. (2005), "Centripetal democratic governance: a theory and global inquiry”, American Political Science Review, Vol. 99 No. 4, pp. 567-581.

Gilpin, R. (1987), The Political Economy of International Relations, Princeton University Press, Princeton, NJ (with the Assistance of Jean M. Gilpin). 
Green, D.P., Kim, S.Y. and Yoon, D.H. (2001), "Dirty pool", International Organization, Vol. 55 No. 2, pp. $441-468$.

Gujarati, D.N. (2003), Basic Econometrics, 4th ed., McGraw-Hill, New York, NY.

Gurr, T.R., Jaggers, K. and Moore, W.H. (1991), "The transformation of the western state: the growth of democracy, autocracy, and state power since 1800", in Inkeles, A. (Ed.), On Measuring Democracy: Its Consequences and Concomitants, Transaction Publishers, New Brunswick and London, pp. 69-104.

Haggard, S. (1986), "The politics of adjustment: lessons from the IMF's extended fund facility", in Kahler, M. (Ed.), The Politics of International Debt, Cornell University Press, Ithaca, NY, and London, pp. 157-186.

Hausman, J. (1978), “Specification tests in econometrics”, Econometrica, Vol. 46 No. 6, pp. 1251-1271.

Henisz, W.J. (2000a), "The institutional environment for economic growth", Economics and Politics, Vol. 12 No. 1, pp. 1-43, available at: www-management.wharton.upenn.edu/henisz/ papers/ieeg.pdf

Henisz, W.J. (2000b), “The institutional environment for multinational corporations”, Journal of Law, Economics, \& Organization, Vol. 16 No. 2, pp. 334-364.

Jensen, N.M. (2003), "Democratic governance and multinational corporations: political regimes and inflows of foreign direct investment”, International Organization, Vol. 57 No. 3, pp. 587-616.

Kaufman, R. and Stallings, B. (1989), "Debt and democracy in the 1980s: the Latin American experience", in Stallings, B. and Kaufman, R. (Eds), Debt and Democracy in Latin America, Westview Press, Boulder, CO, San Francisco, CA, and London, pp. 201-223.

Kiewiet, D.R. and McCubbins, M.D. (1985), "Appropriations decisions as a bilateral bargaining game between president and congress”, Legislative Studies Quarterly, Vol. 10 No. 2, pp. 181-201.

Li, Q. (2005), "Does democracy promote or reduce transnational terrorist incidents?", Journal of Conflict Resolution, Vol. 49 No. 2, pp. 278-297.

MacIntyre, A. (2003), The Power of Institutions: Political Architecture and Governance, Cornell University Press, Ithaca, NY and London.

Manzocchi, S. (1997), "External finance and foreign debt in central and eastern European countries", Working Paper No. 134, Research Department, International Monetary Fund, Washington, DC.

Munck, G. and Verkuilen, J. (2002), "Conceptualizing and measuring democracy: evaluating alternative indices”, Comparative Political Studies, Vol. 35 No. 1, pp. 5-34.

North, D. and Weingast, B. (1989), "Constitution and commitment", Journal of Economic History, Vol. 49 No. 4, pp. 803-832.

Oatley, T. (2010), "Political institutions and foreign debt in the developing world", International Studies Quarterly, Vol. 54 No. 1, pp. 175-195.

Olson, M. (1993), "Dictatorship, democracy, and development", American Political Science Review, Vol. 87 No. 3, pp. 567-576.

Potter, G.A. (2000), Deeper than Debt: Economic Globalisation and the Poor, Latin America Bureau, London.

Roett, R. (1984), "Democracy and debt in South America: a continent's dilemma”, Foreign Affairs, Vol. 62 No. 3, pp. 695-720.

Tsebelis, G. (1995), "Decision making in political systems: veto players in Presidentialism, Parliamentarism, Multicameralism, and Multipartyism”, British Journal of Political Science, Vol. 25 No. 3, pp. 289-325.

Tsebelis, G. (1999), "Veto players and law production in parliamentary democracies: an empirical analysis", American Political Science Review, Vol. 93 No. 3, pp. 591-608.

Tsebelis, G. (2002), Veto Players: How Political Institutions Work, Russell Sage Foundation and Princeton University Press, New York, NY and Princeton, NJ. 
ITPD

3,2

98

Vreeland, J.R. (2007), The International Monetary Fund: Politics of Conditional Lending, Routledge, London and New York, NY.

Wiesner, E. (1985), "Latin American debt: lessons and pending issues", American Economic Review, Vol. 75 No. 2, pp. 191-195.

World Bank (2001), World Development Indicator 2001, World Bank, Washington, DC.

$\mathrm{Yu}, \mathrm{S}$. (2016), "The effect of political factors on sovereign default", Review of Political Economy, Vol. 28 No. 3, pp. 397-416.

\section{Appendix}

\begin{tabular}{|c|c|c|c|c|c|c|}
\hline Algeria & Chile & Fiji & Iran & Morocco & Philippines & Togo \\
\hline Argentina & China & Gabon & Ivory Coast & Nepal & South Korea & Trindidad \& Tobago \\
\hline Bolivia & Colombia & Gambia & Jamaica & Nicaragua & Rwanda & Tunisia \\
\hline Botswana & Comoros & Ghana & Kenya & Nigeria & Senegal & Uruguay \\
\hline Brazil & Congo, Rep. & Guatemala & Lesotho & Oman & South Africa & Venezuela \\
\hline Burkina Faso & Costa Rica & Guinea & Madagascar & Pakistan & Sri Lanka & Zaire \\
\hline Burundi & $\begin{array}{l}\text { Dominican } \\
\text { Republic }\end{array}$ & $\begin{array}{l}\text { Guinea- } \\
\text { Bissau }\end{array}$ & Malawi & Panama & Sudan & Zambia \\
\hline Cameroun & Ecuador & Guyana & Mali & $\begin{array}{l}\text { Papua New } \\
\text { Guinea }\end{array}$ & Swaziland & Zimbabwe \\
\hline $\begin{array}{l}\text { Central } \\
\text { African Rep }\end{array}$ & Egypt & India & Mauritius & Paraguay & Syria & \\
\hline Chad & El Salvador & Indonesia & Mexico & Peru & Thailand & \\
\hline
\end{tabular}

Table AI.

List of sample countries

\begin{tabular}{|c|c|c|}
\hline Variable & Hypothesis & Operationalization (and data sources) \\
\hline Legislative constraints & $\begin{array}{l}\text { The non-linear relationship between } \\
\text { legislative constraints and foreign debt } \\
\text { displays a U-shaped curve }\end{array}$ & $\begin{array}{l}\text { A continuous scale of lowest } 0 \text { to highest } \\
1 \text { (data from Henisz's (2000a, b) collection) }\end{array}$ \\
\hline $\begin{array}{l}\text { Legislative } \\
\text { constraints squared }\end{array}$ & & $\begin{array}{l}\text { A squared term for legislative constraints } \\
\text { (data from Henisz's (2000a, b) collection) }\end{array}$ \\
\hline Economic development & $\begin{array}{l}\text { The higher the economic development, } \\
\text { the lower the foreign debt }\end{array}$ & $\begin{array}{l}\text { The log of GDP per capita (data from } \\
\text { World Bank's (2001) collection) }\end{array}$ \\
\hline Economic growth & $\begin{array}{l}\text { The higher the economic growth, the } \\
\text { lower the foreign debt }\end{array}$ & $\begin{array}{l}\text { Economic growth rate (data from World } \\
\text { Bank's (2001) collection) }\end{array}$ \\
\hline Exports & $\begin{array}{l}\text { The higher the export volume, the } \\
\text { lower the foreign debt }\end{array}$ & $\begin{array}{l}\text { The sum of exports of goods and } \\
\text { services divided by GDP (data from } \\
\text { World Bank's (2001) collection) }\end{array}$ \\
\hline Budget deficit & $\begin{array}{l}\text { The improvement of budget deficit is } \\
\text { likely to reduce foreign debt }\end{array}$ & $\begin{array}{l}\text { The proportion of deficits in GDP (data } \\
\text { from World Bank's (2001) collection) }\end{array}$ \\
\hline Government consumption & $\begin{array}{l}\text { The higher the government } \\
\text { consumption, the higher the } \\
\text { foreign debt }\end{array}$ & $\begin{array}{l}\text { The average general final government } \\
\text { consumption as a percentage of GDP } \\
\text { (data from World Bank's (2001) collection) }\end{array}$ \\
\hline IMF participation & $\begin{array}{l}\text { The IMF participation is likely to } \\
\text { reduce foreign debt }\end{array}$ & $\begin{array}{l}1 \text { for the IMF participation (data from } \\
\text { Vreeland's (2007) collection) }\end{array}$ \\
\hline
\end{tabular}

Table AII.

Hypotheses and operationalization 
Foreign debt

\begin{tabular}{lccrrrr}
\hline Variable & Observations & Mean & SD & Minimum & Maximum & \\
\cline { 1 - 3 } Foreign debt & 892 & 0.0027 & 0.0531 & -0.5374 & 0.4850 & \\
Legislative constraints & 892 & 0.2036 & 0.2141 & 0.0000 & 0.6547 & \\
Legislative constraints squared & 892 & 0.0872 & 0.1095 & 0.0000 & 0.4287 & \\
Economic development & 892 & 6.9869 & 1.0325 & 4.7265 & 9.3872 & \\
Economic growth & 892 & 1.1694 & 4.9349 & -16.3590 & 34.5970 & \\
Exports & 892 & 28.2342 & 15.1123 & 3.3383 & 80.3273 & \\
Budget deficit & 892 & -3.7863 & 6.1287 & -61.1410 & 20.6260 & \\
Government consumption & 892 & 14.0642 & 5.8826 & 2.9755 & 45.9590 & Table AIII. \\
IMF participation & 892 & 0.5157 & 0.5000 & 0.0000 & 1.0000 & Descriptive statistics \\
\end{tabular}

\begin{tabular}{|c|c|c|c|c|}
\hline & Model 1 & Model 2 & Model 3 & Model 4 \\
\hline Constant & $-0.0118(0.0152)$ & $-0.0123(0.0151)$ & $0.8661(0.7887)$ & $0.8802(0.7828)$ \\
\hline Legislative constraints & $-0.0049(0.0097)$ & $-0.0672 * *(0.0344)$ & $-0.0008(0.0103)$ & $-0.0636 * *(0.0346)$ \\
\hline Legislative constraints ${ }^{2}$ & & $0.1219 * * *(0.0651)$ & & $0.1231 * *(0.0654)$ \\
\hline Economic development & $0.0029 *(0.0022)$ & $0.0034^{*}(0.0022)$ & $0.0026(0.0022)$ & $0.0032 *(0.0022)$ \\
\hline Economic growth & $-0.0024 * * *(0.0004)$ & $-0.0024 * * *(0.0004)$ & $-0.0024 * * *(0.0004)$ & $-0.0024 * * * *(0.0004)$ \\
\hline Exports & $-0.0005 * * *(0.0001)$ & $-0.0005^{* * *}(0.0001)$ & $-0.0005^{* * * *}(0.0001)$ & $-0.0005 * * *(0.0001)$ \\
\hline Budget deficit & $-0.0022 * * *(0.0004)$ & $-0.0024 * * *(0.0004)$ & $-0.0022 * * *(0.0004)$ & $-0.0023 * * *(0.0004)$ \\
\hline Government & & & & \\
\hline consumption & $0.0006^{*}(0.0004)$ & $0.0004(0.00$ & $0.0005(0.0004)$ & $0.0003(0.0004)$ \\
\hline IMF participation & $-0.0073^{* *}(0.0037)$ & $-0.0073 * *(0.0037)$ & $-0.0072 * *(0.0037)$ & $-0.0072 * *(0.0037)$ \\
\hline Time changes & & & $-0.0004(0.0004)$ & $-0.0004(0.0004)$ \\
\hline
\end{tabular}

Notes: Standard errors in parentheses. ${ }^{*} p<0.10 ; * * p<0.05 ; * * p<0.01$

Table AIV.

The effect of legislative constraints on foreign debt: FGLS

\section{Corresponding author}

Seung-Whan Choi can be contacted at: whanchoi@uic.edu

For instructions on how to order reprints of this article, please visit our website: 